\title{
OPEN Author Correction: The Reaction of Dimerization by Itself Reduces the Noise Intensity of the Protein Monomer
}

\author{
Feng-You Liu, Shih-Chiang Lo \& Che-Chi Shu \\ Correction to: Scientific Reports https://doi.org/10.1038/s41598-019-39611-6, published online 04 March 2019 \\ In the Supplementary Material file originally published with this Article, text was omitted from the 'Text S2' sec- \\ tion. This error has been corrected in the Supplementary Information that now accompanies the Article.
}

\begin{abstract}
(c) (i) Open Access This article is licensed under a Creative Commons Attribution 4.0 International License, which permits use, sharing, adaptation, distribution and reproduction in any medium or format, as long as you give appropriate credit to the original author(s) and the source, provide a link to the Creative Commons license, and indicate if changes were made. The images or other third party material in this article are included in the article's Creative Commons license, unless indicated otherwise in a credit line to the material. If material is not included in the article's Creative Commons license and your intended use is not permitted by statutory regulation or exceeds the permitted use, you will need to obtain permission directly from the copyright holder. To view a copy of this license, visit http://creativecommons.org/licenses/by/4.0/.
\end{abstract}

(c) The Author(s) 2020 